\title{
The Early Days of Research on Carbonic Anhydrase
}

\author{
HORACE W. DAVENPORT \\ Department of Physiology \\ The University of Michigan \\ Ann Arbor, Michigan 48109
}

My first encounter with the combination of F. J. W. Roughton and carbonic anhydrase occurred on the afternoon of Friday, June 18, 1937, when I sat for the fourth paper in the Final Honour School of Animal Physiology at Oxford University (FIG. 1). Roughton was the External Examiner, and C. W. Carter and E. G. T. Liddell were the Internal Examiners. The paper they set contained twelve questions, and it was headed: "Candidates are asked to attempt NOT LESS THAN THREE and NOT MORE THAN FOUR questions." The first question was in German and the second in French. The sixth question was: "Explain how carbonic anhydrase came to be discovered and give an account of its properties and functions." I attempted to answer the German question, not in German I am afraid, and one about the determination of $\mathrm{pH}$ in biological materials, but I did not tackle the sixth question. I didn't know enough to do so. Now, a little over fortysix years later, I shall attempt to say how carbonic anhydrase came to be discovered and leave its properties and functions to others at this conference.

The description of blood as a physical chemical system has been a major accomplishment of physiology. Cambridge University was one of the centers of the work, largely because Joseph Barcroft had started his career there attempting to measure oxygen consumption of salivary glands. ${ }^{1}$ That led him to measurement of the combination of oxygen with hemoglobin. One brilliant Cambridge physiologist said to me, "You know, Barcroft was a very stupid man. He got all hot and bothered if you suggested he use a logarithm." The only trouble with that judgment is that, from the day he started until the day he died at the age of 75, Barcroft made profoundly important contributions to physiology. ${ }^{2}$

Francis John Worsley Roughton was a Cambridge undergraduate during the First World War, and he was fortunate in having paroxysmal tachycardia. He didn't go into the army and be killed as most of his contemporaries were. His case history has been published. "In two attacks of paroxysmal tachycardia in which the pulse was upwards of 200 the minute-volume sank from 5-6.1 litres to 2.8-2.1 litres per minute, or roughly to half to a third of the normal value. . . The systolic output was 77.5 to 12.9 c.c. " 3 Roughton was scheduled to give a paper on hemoglobin to one of the innumerable undergraduate clubs that abound in Cambridge and Oxford. When he read Barcroft's papers, he discovered that Barcroft really didn't understand the work being done by Bohr and his school in Copenhagen. Characteristically, Roughton went up to Barcroft and said, in effect, "Dr. Barcroft, you don't know what you are talking about." Barcroft demonstrated how to be a great man by replying, "Wonderful, come work with me and show me how to do it right." From then on, Roughton's devotion to Barcroft was unbounded.

The experiments that established the physical chemical nature of blood were all equilibrium studies. One took a sample of blood from Arlie V. Bock or from a 
Manchurian pony, rotated it in a tonometer for fifteen or so minutes and then analyzed the blood and the gas phase. The results demonstrated, so it was thought, that most carbon dioxide is carried from the tissues to the lungs as bicarbonate. ${ }^{4}$ Henriques of Copenhagen (FIG. 2) was the only one who paid attention to the proof given by Thiele ${ }^{5}$ and by Faurholt ${ }^{6}$ that hydration and dehydration of carbon dioxide are relatively slow processes. Henriques wrote (in German) what we always tell medical students nowadays:

The length of the capillary is $0.3 \mathrm{~mm}$, and the velocity of circulation in the capillaries is $0.3 \mathrm{~mm}$ a second; in the course of 1 second blood passes through the lung capillaries. During this second blood must take up $\mathrm{O}_{2}$ from the alveolae and give off $\mathrm{CO}_{2}$. The velocity of diffusion of $\mathrm{O}_{2}$ as well as of $\mathrm{CO}_{2}$ is so great that the exchange is physically possible. The chemical combination of $\mathrm{O}_{2}$ and hemoglobin, according to Hartridge and Roughton, is so fast that the exchange of oxygen is possible.

The velocity of the uptake and release of carbon dioxide in blood has never been measured. ${ }^{7}$

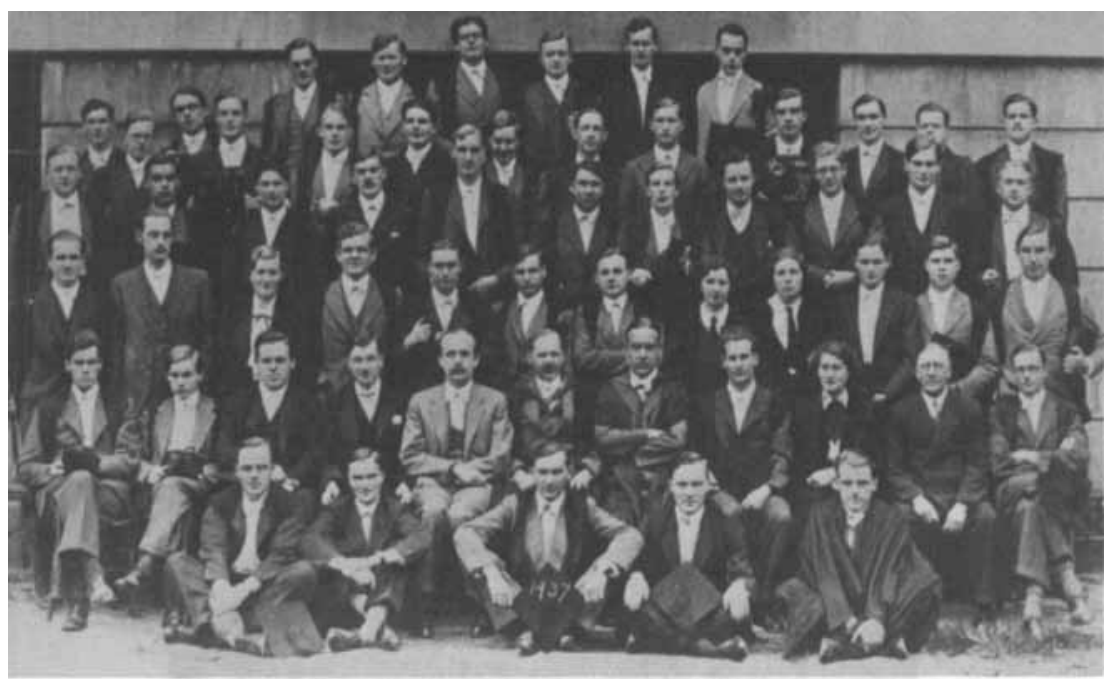

FIGURE 1. Examiners and candidates in the Oxford University Final Honour School of Animal Physiology, 1937. F. J. W. Roughton in a grey suit and looking less disheveled than usual is the third examiner on the left. The other two in correct subfusc are C. W. Carter and E. G. T. Liddell. H. W. Davenport is the second from the left in the first standing row.

Henriques knew that the reversible reaction between carbon dioxide and an amine is fast, and he made some good measurements by means of dialysis of the amount of carbamino- $\mathrm{CO}_{2}$ carried by reduced and oxygenated hemoglobin. He then measured the rate of release of carbon dioxide by a relatively crude "explosion method" in which he suddenly exposed blood to a vacuum, and he concluded, "The carriage of carbon dioxide in blood is exclusively as carbamino-hemoglobin; bicarbonate and carbonic acid play a subordinate part in respiration."

The Hartridge-Roughton work, ${ }^{8}$ referred to by Henriques, shows that already in the early 1920s Roughton was thinking about rates of reaction in blood. 
Van Slyke, for reasons that turned out to be inadequate, had rejected the presence of carbamino- $\mathrm{CO}_{2}$ in blood, and he immediately took up Henriques's challenge. He confirmed the observation that carbon dioxide comes off an evacuated solution of hemoglobin much faster than it should if uncatalyzed reactions dominated the rate. However, he showed that a little bit of hemoglobin accelerates carbon dioxide output just as well as a large amount. Therefore, hemoglobin

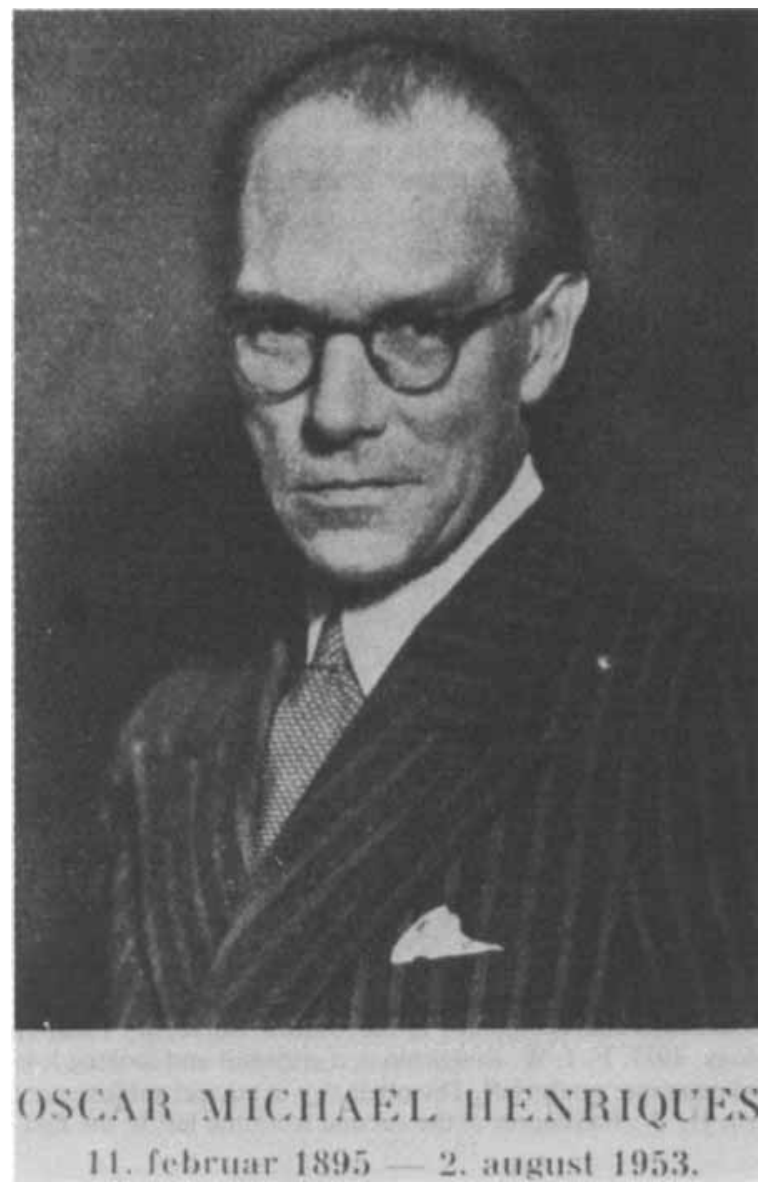

FIGURE 2. O. M. Henriques. (From Ugeskrift for Laeger. 1953. 115: 1348.)

must catalyze some one of the reactions resulting in evolution of $\mathrm{CO}_{2}$ from bicarbonate. For no reason whatever, Van Slyke concluded that "the rapidity of evolution of $\mathrm{CO}_{2}$ from evacuated blood solutions appears to be best described as due to a catalytic acceleration by the cell contents of the reaction $\mathrm{HCO}_{3}^{-}+\mathrm{H}^{+} \rightleftharpoons$ $\mathrm{H}_{2} \mathrm{CO}_{3} .{ }^{9}$ 
In the early $1930 \mathrm{~s}$, those who thought hemoglobin catalyzes the hydration and dehydration of carbon dioxide prepared their hemoglobin by Adair's method. Gilbert Adair had proved that purified hemoglobin is a molecule with a definite molecular weight, ${ }^{10}$ and anyone who used his method of purification thought the product was pure. But it wasn't. The crucial observation was made when Meldrum and Roughton shook up laked blood with chloroform, centrifuged the mixture and found catalytic activity in the hemoglobin-free supernatant. ${ }^{11}$ Everyone concerned is dead now, and it is impossible to tell whose idea it was to separate the catalytic activity that way from hemoglobin. The method produced a horrible mess. Even in those days it was cheaper to discard the centrifuge tube than to clean out the coagulated hemoglobin. Then Philip Eggleton suggested the name carbonic anhydrase.

Meldrum and Roughton found carbonic anhydrase in red blood cells but not in plasma. I have never been able to understand Roughton's explanation for the exclusion of carbonic anhydrase from plasma, for I thought equilibrium is independent of path. Perhaps Robert Forster can give an explanation based upon rates of diffusion of bicarbonate and chloride through the red blood cell's membrane. The real reason is that carbonic anhydrase, on account of its low molecular weight, would be quickly cleared from plasma by the kidneys. ${ }^{12}$

Roughton was not, to put it gently, an accomplished technician in the laboratory. My guess is that after Meldrum's death, when Roughton had to finish the work himself, he missed finding carbonic anhydrase in other tissues by sheer ineptitude. Carbonic anhydrase became a popular topic, the prostaglandin of its day, and others soon found it in many vertebrate and invertebrate tissues. ${ }^{13}$ Sometimes a function could be assigned, as in shell formation in a bird's oviduct, ${ }^{14}$ but more often the postulated function was fanciful. The demonstration that carbonic anhydrase is present in high concentration in the oxyntic cells of the gastric mucosa ${ }^{15}$ attracted a lot of attention for the reason that it provided the first hard biochemical evidence concerning the mechanism of acid secretion. Here, too, the upshot has been disappointing, for it is nearly impossible to inhibit acid secretion by inhibiting carbonic anhydrase. ${ }^{16}$

David Keilin (pronounced Kayleen and not Kylin) was the Cambridge authority on metallo-proteins. After he and his collaborator, Thaddeus Mann (FIG. 3), had isolated hemocuprein from red blood cells, they had a lot of protein and a lot of zinc left over. It was a short step to show that the protein is zinc-containing carbonic anhydrase. ${ }^{17}$

It is a rule that a drug has no side effects in its first five years. By 1939 time was running out for the sulfonamide drugs, and physicians frequently observed that treatment with sulphanilamide (in England) or with sulfanilamide (in the United States) caused a fall in the carbon dioxide combining power of blood. ${ }^{18,19}$ One Sunday morning, it occurred to Thaddeus Mann that the effect of the drug on carbon dioxide combining power might be explained if sulfanilamide inhibits carbonic anhydrase. The train of logic here is not at all clear to me. Mann was not thinking of carbonic anhydrase in the kidney, for the enzyme had not yet been demonstrated to be present there. Anyway, he went to the laboratory to find that his supposition was, in fact, correct. ${ }^{20}$ That was the beginning of a long story that is not yet finished. When carbonic anhydrase was found in the kidney, ${ }^{21}$ Rudolph Höber showed that those sulfonamide drugs that inhibit carbonic anhydrase also inhibit renal acid secretion. ${ }^{22}$ One of his drugs irreversibly inhibited renal acid secretion, but so far as I know that fact has not been followed up. Shortly thereafter came Maren's measurement of sodium-losing promoted by acetazolamide ${ }^{23}$ and Robert Pitts's description of the handling of carbon dioxide by the kidney. ${ }^{24}$ 


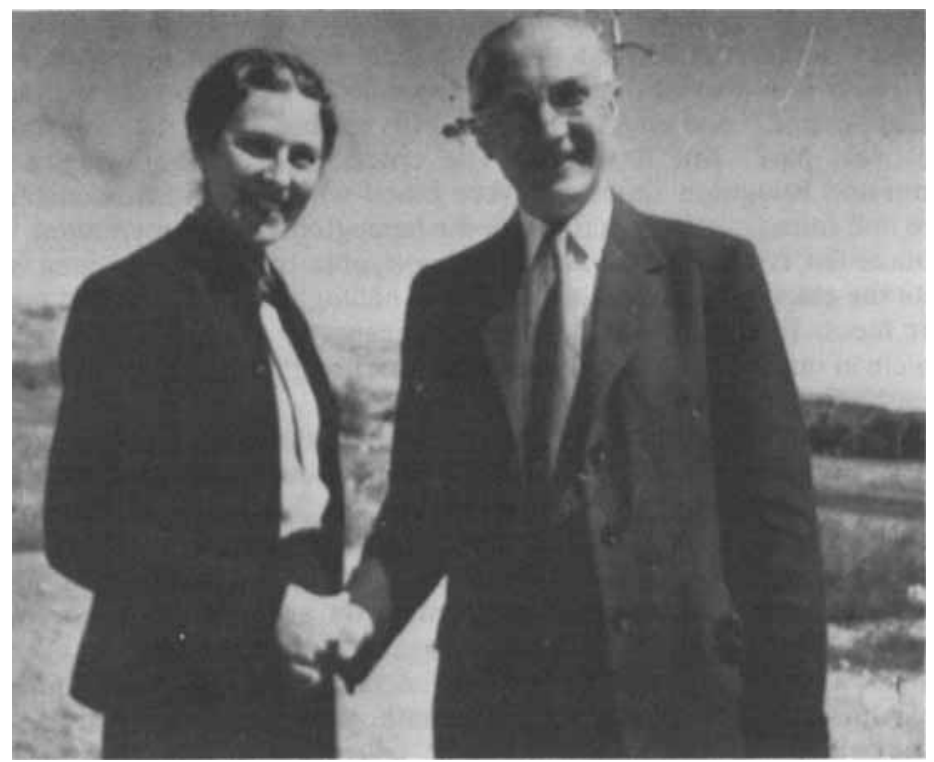

FIGURE 3. Cecelia Lutwak-Mann and Thaddeus Mann in the Salt Lake City Airport, September 1955.

Just to show that the story of the physiological role of carbonic anhydrase is not finished, I remind members of this conference that Cecelia Lutwak-Mann, Thaddeus Mann's wife, long ago demonstrated that there is a high concentration of carbonic anhydrase in the endometrium of the pregnant rabbit, in the placenta, and in the Fallopian tubes and that the enzyme is under control of progesterone. ${ }^{25}$ Perhaps someone here can explain the significance of those facts.

\section{REFERENCES}

1. Barcroft, J. 1901. The gaseous metabolism of the submaxillary gland. J. Physiol. 27: $31-47$.

2. Franklin, K. J. 1953. Joseph Barcroft. Blackwell Scientific Publications. Oxford.

3. Barcroft, J., A. V. Bock \& F. J. Roughton. 1921. Observations on the circulation and respiration in a case of paroxysmal tachycardia. Heart 9: 7-13.

4. Henderson, L. J. 1928. Blood. Yale University Press. New Haven, CT.

5. ThIEle, A. 1913. Über die langsame Neutralisation der Kohlensäure. Ber. Dtsch. Chem. Ges. 46: 241-244.

6. Faurholt, C. 1924. Études sur les solutions aqueuses d'anhydride carbonique et d'acide carbonique. J. Chim. Phys. 21: 400-455.

7. Henriques, O. M. 1928. Die Bindungsweise des Kohlendioxids im Blute. Biochem. Z. 200: $1-4,4-9,10-17,18-21,22-24$.

8. Hartridge, H. \& F. J. W. Roughton. 1923. The kinetics of haemoglobin. II. The velocity with which oxygen dissociates from its combination with haemoglobin. Proc. R. Soc. London Ser. A 104: 395-430.

9. VAN SlyKe, D. D. \& J. A. Hawkins. 1930. Studies of gas and electrolyte equilibria in 
blood. XVI. The evolution of carbon dioxide from blood and buffer solutions. J. Biol. Chem. 87: 265-279.

10. ADAIR, G. S. 1924. A comparison of osmotic pressures of oxyhaemoglobin, reduced haemoglobin and methaemoglobin. J. Physiol. 58: xxxix.

11. Meldrum, N. U. \& F. J. W. Roughton. 1933. Carbonic anhydrase. Its preparation and properties. J. Physiol. 80: 113-142.

12. DAvenPoRT, H. W. 1945. The renal clearance of carbonic anhydrase. Fed. Proc. 4: 16.

13. DavenPort, H. W. 1946. Carbonic anhydrase in tissues other than blood. Physiol. Rev. 26: 560-573.

14. Common, R. H. 1941. The carbonic anhydrase activity of the hen's oviduct. J. Agric. Sci. 31: $412-414$.

15. DavenPoRt, H. W. 1939. Gastric carbonic anhydrase. J. Physiol. 97: 32-43.

16. DAVENPORT, H. W. 1946. In memoriam: The carbonic anhydrase theory of gastric acid secretion. Gastroenterology 7: 374-375.

17. Keilin, D. \& T. Mann. 1940. Carbonic anhydrase. Purification and nature of the enzyme. Biochem. J. 34: 1163-1176.

18. SouthWORTH, H. 1937. Acidosis associated with administration of para-amino-benzene-sulfonamide. Proc. Soc. Exp. Biol. Med. 36: 58-61.

19. JAMES, G. V. 1940. The effect of administration of acetate on the detoxication and therapeutic activity of sulphanilamide. Biochem. J. 34: 633-635.

20. ManN, T. \& D. KeILIN. 1940. Sulphanilamide as a specific inhibitor of carbonic anhydrase. Nature 146: 164-165.

21. Davenport, H. W. \& A. E. Wilhelmi. 1941. Renal carbonic anhydrase. Proc. Soc. Exp. Biol. Med. 48: 53-56.

22. HöBER, R. 1942. Effect of some sulfonamides on renal secretion. Proc. Soc. Exp. Biol. Med. 49: 87-90.

23. Maren, T. H., B. C. Wadsworth, E. K. Yale \& L. G. Alonso. 1954. Carbonic anhydrase inhibition. III. Effects of Diamox ${ }^{\circledR}$ on electrolyte metabolism. Bull. Johns Hopkins Hosp. 95: 277-321.

24. Pitts, R. F. \& R. S. AleXander. 1945. The nature of the renal tubular mechanism for acidifying the urine. Am. J. Physiol. 144: 239-254.

25. LutWak-ManN, C. 1955. Carbonic anhydrase in the female reproductive tract. Occurrence, distribution and hormonal dependence. J. Endocrinol. 13: 26-38. 